\title{
Recognizing order in chaotic sequences of Quaternary sediments in the Canadian Cordillera
}

\author{
John J. Clague* \\ Department of Earth Sciences, Simon Fraser University, Institute for Quaternary Research, 8888 University Drive, Burnaby, B.C., Canada V5A 1S6
}

\begin{abstract}
Episodic growth and decay of the Cordilleran ice sheet during the Pleistocene has imposed order on Quaternary stratigraphies in British Columbia and southern Yukon Territory. Although Quaternary deposits in this region are inherently complex, thick valley and lowland fills consist of discrete packages of glacial sediments separated by unconformities or by generally thin, patchy interglacial deposits. Some unconformities define former valley and lowland landscapes of similar relief to the present. Each package of glacial sediments displays stratigraphic order: distinctive fluvial and lacustrine units, deposited during the early stage of a glaciation and later overridden and eroded by glaciers, are overlain by retreat phase and interglacial fluvial, lacustrine, and marine sediments. Packages of glacial sediments contain one or more unconformities produced by glacial erosion; commonly the unconformities are better stratigraphic markers than tills, which are not always present, especially in valleys. The Quaternary stratigraphic record in the Canadian Cordillera becomes less complete with age, owing to repeated erosion during both interglaciations and glaciations. The most complete glacial sequence is the youngest, deposited during the late Wisconsin Fraser Glaciation. Deposits of the penultimate glaciation are common but generally incomplete. Only sporadic remnants of older, apparently Middle and Early Pleistocene glacial deposits are present in the Cordillera. (C) 2000 Elsevier Science Ltd and INQUA. All rights reserved.
\end{abstract}

\section{Introduction}

Thick Quaternary sediments in the Canadian Cordillera occur mainly in coastal lowlands and river valleys, where they form complex sequences of nested, lithologically variable units. Unconformities may lie within these sequences, and facies may vary considerably over short distances. Because of this complexity, it is difficult to recognize the stratigraphic order that is invariably present. This is unfortunate, for an appreciation of stratigraphic order and its relation to Quaternary history is essential for many professional activities, including geotechnical evaluation of complex sediment sequences, ground-water studies, and surficial geology mapping, to name a few.

In this paper, I present a contextual framework for Quaternary stratigraphic successions in the glaciated Canadian Cordillera, in part to provide guidance to students and professionals involved in the study of Quaternary deposits. I start with a brief overview of the style of Pleistocene glaciation in the Canadian Cordillera, for

\footnotetext{
* Corresponding author. Fax: 1-604-291-4198.

E-mail address: jclague@sfu.ca (J.J. Clague).
}

an understanding of the buildup and decay of the Cordilleran ice sheet is critical to properly interpreting stratigraphies. I then turn to the character and stratigraphic position of units in Quaternary sequences and to relations of the units to unconformities.

\section{Pleistocene glaciation}

The Pleistocene Epoch in the Canadian Cordillera was marked by the repeated growth and decay of the Cordilleran ice sheet (Fig. 1). Isotopic and magnetic studies of deep-sea sediments have provided evidence for eight major climatic cycles in the last $800,000 \mathrm{yr}$, each about $100,000 \mathrm{yr}$ in duration and each punctuated by sharp fluctuations in climate on shorter time scales. These cycles were preceded back to before the beginning of the Pleistocene by similar cycles of lesser magnitude but greater frequency (Shackleton and Opdyke, 1973, 1976). Many or most of the climatic cycles were probably accompanied by widespread glaciation in the Canadian Cordillera.

During interglaciations, ice was restricted to high mountains, much as today (Fig. 2a). Climatic cooling at the beginning of each glaciation caused glaciers to 


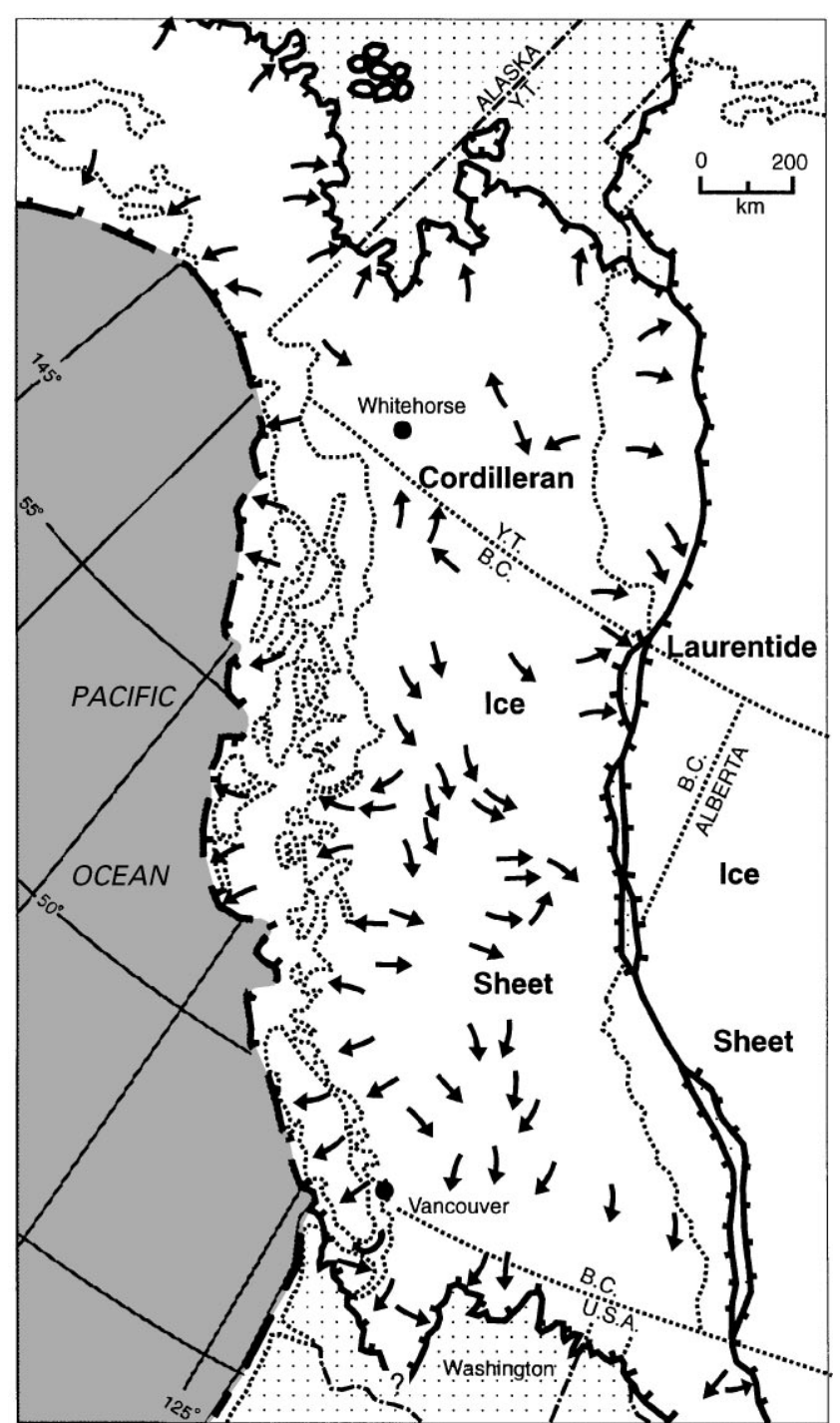

Fig. 1. Map showing the maximum extent of Pleistocene glaciation in the Canadian Cordillera and adjacent areas, ice-flow pattern during late Wisconsin glaciation, and place names mentioned in the paper. The glacier complex includes the Cordilleran ice sheet and independent glacier systems in peripheral mountain ranges. Nunataks were small in ice-sheet areas at the climax of glaciation. In contrast, there were large ice-free areas in some bordering mountain ranges. Modified from Flint (1971, Fig. 18.1).

expand (Fig. 2b) and vegetation and hydrology to change. Over periods of hundreds to thousands of years, valley glaciers advanced and overtopped intervalley ridges to coalesce as small mountain ice sheets (Kerr, 1934; Davis and Mathews, 1944). Eventually, glaciers spread across the plateaus of the British Columbia and Yukon interior, and into lowlands along the Pacific coast. At the peaks of great Pleistocene glaciations, piedmont and valley glaciers from separate mountain ranges coalesced to bury the interior region and parts of the continental shelf (Fig. 2c). The buildup of glacier ice triggered complex isostatic depression of the land surface

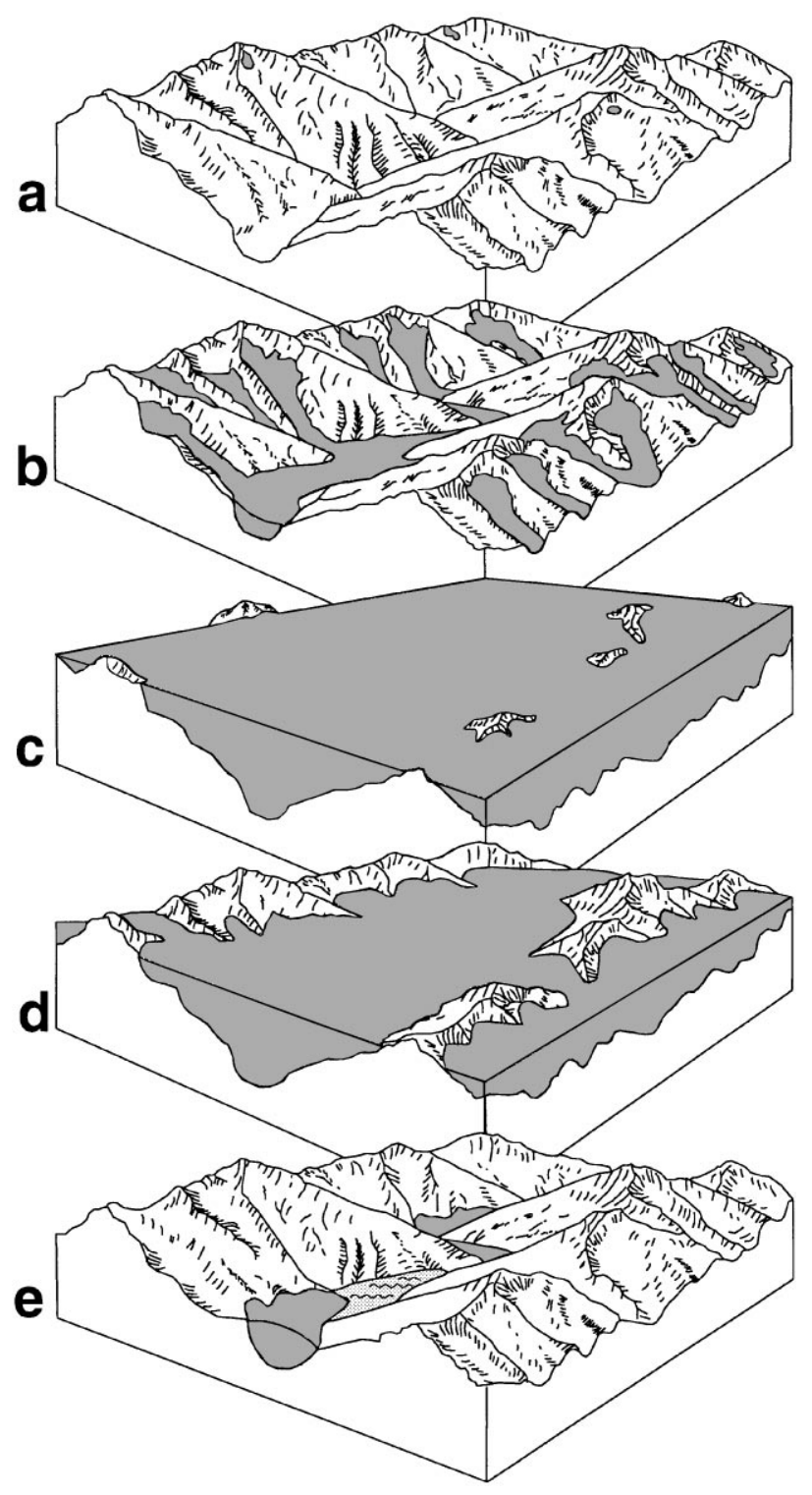

Fig. 2. Growth and decay of the Cordilleran ice sheet: (a) mountain area at the beginning of a glaciation; (b) development of a network of valley glaciers; (c) coalescence of valley and piedmont lobes to form an ice sheet; (d) decay of ice sheet by down wasting; upland areas are deglaciated before adjacent valleys; (e) residual dead ice masses confined to valleys. Modified from Clague (1989, Fig. 1.13).

(Clague, 1983) and led to a radical restructuring of drainage established during the preceding interglaciation.

The pattern of glacier retreat was not a mirror image of the pattern of glacier advance (Fulton, 1991). The Cordilleran ice sheet decayed by downwasting, with complex frontal retreat along the coast and widespread stagnation in the interior (Fulton, 1967, 1991; Clague, 1981)(Figs. 2d and e). Coastal lowlands were flooded by the sea as glaciers, destabilized by eustatically rising water levels, calved back into fiords. In areas of low and moderate relief in the interior, deglaciation proceeded by stagnation, with uplands appearing through the ice cover first 
and dividing the ice sheet into a series of tongues that decayed in response to local conditions. Isostatic uplift accompanied deglaciation; areas at the periphery of the ice sheet rebounded first, and the interior later.

If the last glacial cycle is representative of Pleistocene glaciations, periods of ice-sheet growth were longer than periods of ice-sheet decay. The Cordilleran ice sheet during the Fraser Glaciation (late Wisconsin, marine oxygen isotope stage 2) developed over 10,000-15,000 yr, but it disappeared in less than $5000 \mathrm{yr}$ (Clague, 1981; Clague et al., 1990).

The pattern of ice-sheet growth and decay was probably more complex than suggested above, making interpretation of sedimentary successions more difficult. Brief intervals of glacier recession likely interrupted the growth of the ice sheet, and local still stands and readvances occurred during ice-sheet decay. A continental ice sheet formed only during some glaciations. Other glaciations culminated with an ice cover consisting of many separate glacier complexes confined to, or spreading some distance beyond, mountain ranges. At these times, significant plateau areas, some coastal lowlands, and parts of the continental shelf remained ice-free. Fullblown ice sheets did, however, develop during the last two glacial cycles (late and early Wisconsin). Much of the exposed Quaternary stratigraphy in the Cordillera is a product of these two events.

\section{Concepts}

Concepts that are crucial to understanding Quaternary sedimentary successions in the Canadian Cordillera are episodic sedimentation, regional differences in the character of deposits, stratigraphic order imposed by ice-sheet growth and decay, and long-term alternation of deposition and erosion expressed in unconformities and nesting of units.

\subsection{Episodic sedimentation}

The terrestrial Quaternary sediment record in the Canadian Cordillera is largely a product of brief depositional events separated by long periods of nondeposition and erosion (Clague, 1986). Most stratigraphic units in valleys and coastal lowlands consist of stratified drift (silt, sand, and gravel) deposited during periods of growth and decay of the Cordilleran ice sheet that were thousands of years to $20,000 \mathrm{yr}$ long. At specific sites, however, thick stratified drift units may have accumulated in only centuries or decades.

In contrast, during interglaciations, sedimentation was slower and occurred over but a tiny fraction of the landscape. The only important terrestrial sedimentation sites during interglaciations are lakes, flood plains, and fans, which today constitute less than $5 \%$ of the land area of the Canadian Cordillera. Therefore, stratigraphic records of these periods are meager. Some large lakes and valleys that were not deeply scoured by glaciers do contain significant interglacial sediment fills, but these fills are generally below present-day base level and thus are encountered only during drilling and in deep excavations. As explained below, thick stratified units above present base level were deposited during periods of glacier advance and retreat, not during interglaciations.

\subsection{Regional differences in sedimentary sequences}

Physiography has controlled Quaternary sedimentation in the Canadian Cordillera. The main terrestrial sediment accumulation areas have been valleys and coastal lowlands. Thick Quaternary deposits in these areas are dominated by stratified drift deposited during periods of growth and decay of the Cordilleran ice sheet. Till is a subordinate element of the stratigraphy in coastal lowlands and is uncommon in valley fills. Sediment fills in valleys and coastal lowlands were partially removed during interglaciations, and the products of erosion moved to flood plains, lakes, and the sea.

Quaternary deposits on the vast plateaus of interior British Columbia and Yukon are very different from those in river valleys. The plateaus are covered mainly by till; stratified drift is more localized and less important in these areas than in valleys. Unlike valleys, plateaus experience neither significant deposition nor erosion during interglacial periods, except near streams and where relief is high. But during glaciations, large amounts of till on plateaus were eroded and redeposited by glaciers and subglacial meltwater.

\subsection{Sedimentation during glacier advance}

Some of the most extensive and conspicuous Quaternary stratigraphic units in the Canadian Cordillera were deposited during times of growth of the Cordilleran ice sheet (Figs. 3 and 4). Cooling and glacier expansion triggered an increase in sediment production, especially in alpine areas. Initially, much of the sediment accumulated as outwash in mountain valleys. But as glaciers advanced out of the mountains, much of this material and also colluvial and fluvial sediments of the preceding interglaciation were flushed from these staging areas into intermontane valleys and fiords. Unable to cope with the large amounts of sediment made available to them, streams aggraded their valleys, raising base level. Substantial amounts of sediment accumulated in this way in short periods of time. Sites of deposition shifted as glaciers advanced, thus aggradation occurred at different times in different places. As glaciers continued to expand, they increasingly disrupted the pre-glacial drainage and impounded large, rapidly changing lakes in which 


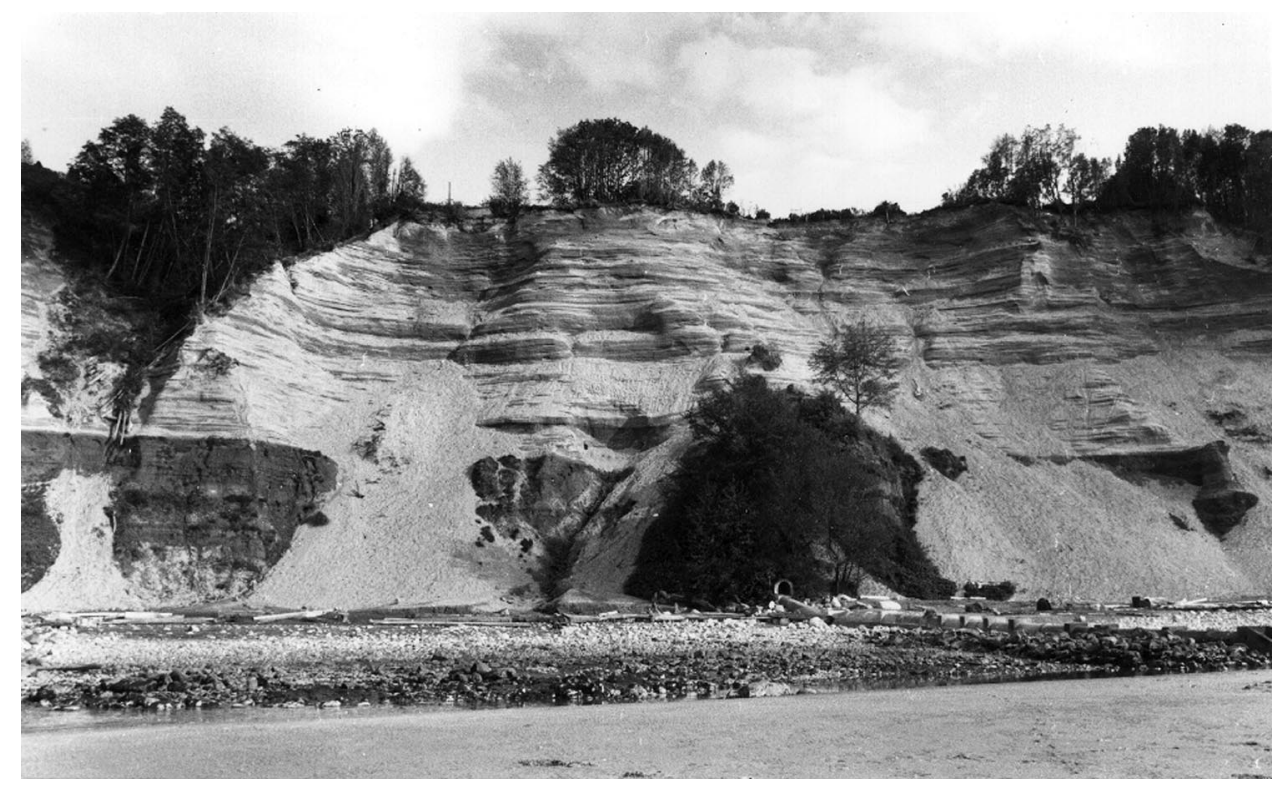

Fig. 3. Sandy outwash (Quadra Sand) deposited during the advance phase of the Fraser Glaciation, Vancouver, British Columbia. The lower darker part of the unit contains interbeds of silt.

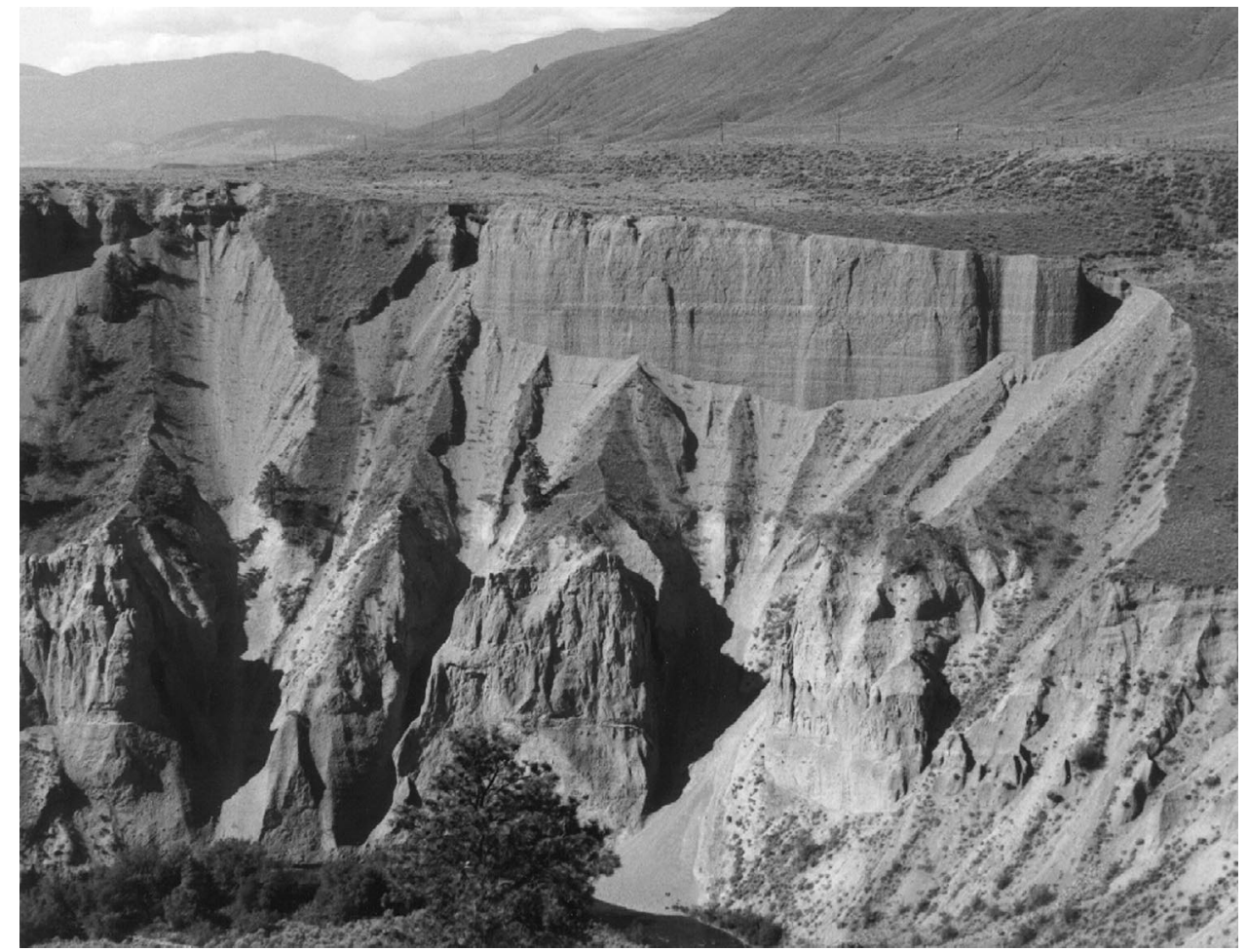

Fig. 4. Gravelly advance outwash deposited during the early part of the Fraser Glaciation near Ashcroft, British Columbia. Similar sediments are present in many valleys in the British Columbia interior.

a variety of sediments accumulated (Eyles and Clague, 1987, 1991; Huntley and Broster, 1994).

The typical sedimentary sequence resulting from such events comprises glaciofluvial/deltaic gravel or sand, conformably overlain by glaciolacustrine sand and silt
(Fig. 5). The glaciofluvial sediments are cross-bedded gravel and sand up to $100 \mathrm{~m}$ thick. Gravel dominates interior valleys, whereas sand occurs locally along the British Columbia coast. These units are excellent markers that facilitate local and regional correlation of 
Quaternary sequences (Clague, 1976). Deltaic sand and silt occur with the glaciofluvial sediments where proglacial streams entered a lake or the sea. The deltaic sediments may conformably underlie or overlie fluvial

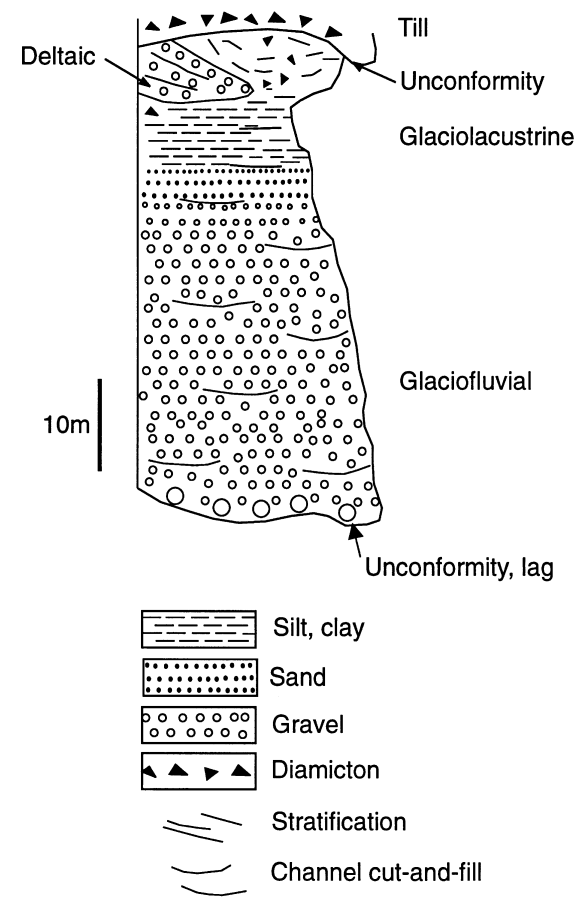

Fig. 5. Generalized stratigraphy of sediments deposited during the advance phase of a glaciation. The advance culminates in glacier overriding, erosion, and deposition of till. facies. The former situation is more likely along the coast where meltwater streams entered the sea; the latter is typical of interior valleys where lakes developed behind glacier or sediment dams. Deltaic facies may grade laterally into or be conformably overlain by glaciolacustrine silt and clay deposited farther from stream mouths.

Such stratigraphy reflects a continuous build-up of glacier ice, uninterrupted by retreat. More complicated stratigraphies, interrupted by unconformities and multiple glaciofluvial and glaciolacustrine units, may occur where two or more advances of one glaciation were separated by glacier retreat. Most stratigraphic sequences in the core area of the former Cordilleran ice sheet record only one advance (e.g., Fulton, 1975; Fulton and Smith, 1978; Clague, 1987, 1988). Evidence for more than one advance has been found in areas nearer to the margin of the former ice sheet, for example, near Vancouver (Hicock et al., 1982) and in the southern Rocky Mountain Trench (Clague, 1975).

\subsection{Sedimentation during glacier retreat}

Aggradation on a similar scale to that of periods of ice-sheet growth also occurred at the ends of glaciations and during the earliest part of subsequent interglaciations (Church and Ryder, 1972) (Figs. 6 and 7). Wasting ice masses released large quantities of sediment. The fresh unstable drift was mobilized by gravity and running water, transported into valleys, and redeposited on fans and flood plains and in lakes. Glaciomarine sediments accumulated on isostatically depressed lowlands along

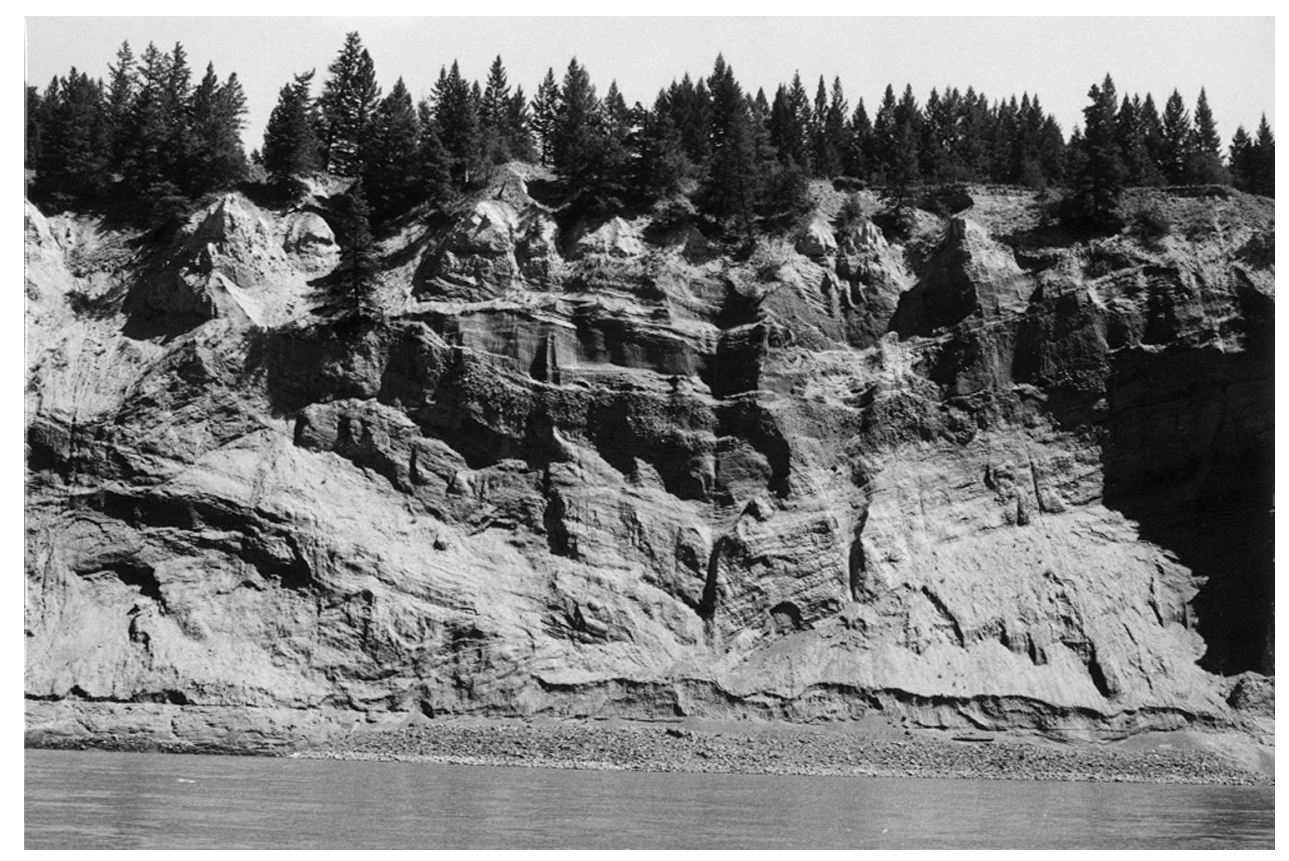

Fig. 6. Intertonguing silt, sand, gravel, and diamicton deposited against or on top of stagnant ice in a Pleistocene glacier-dammed lake in the Fraser River valley in central British Columbia. The sediments were deformed when the ice melted. 


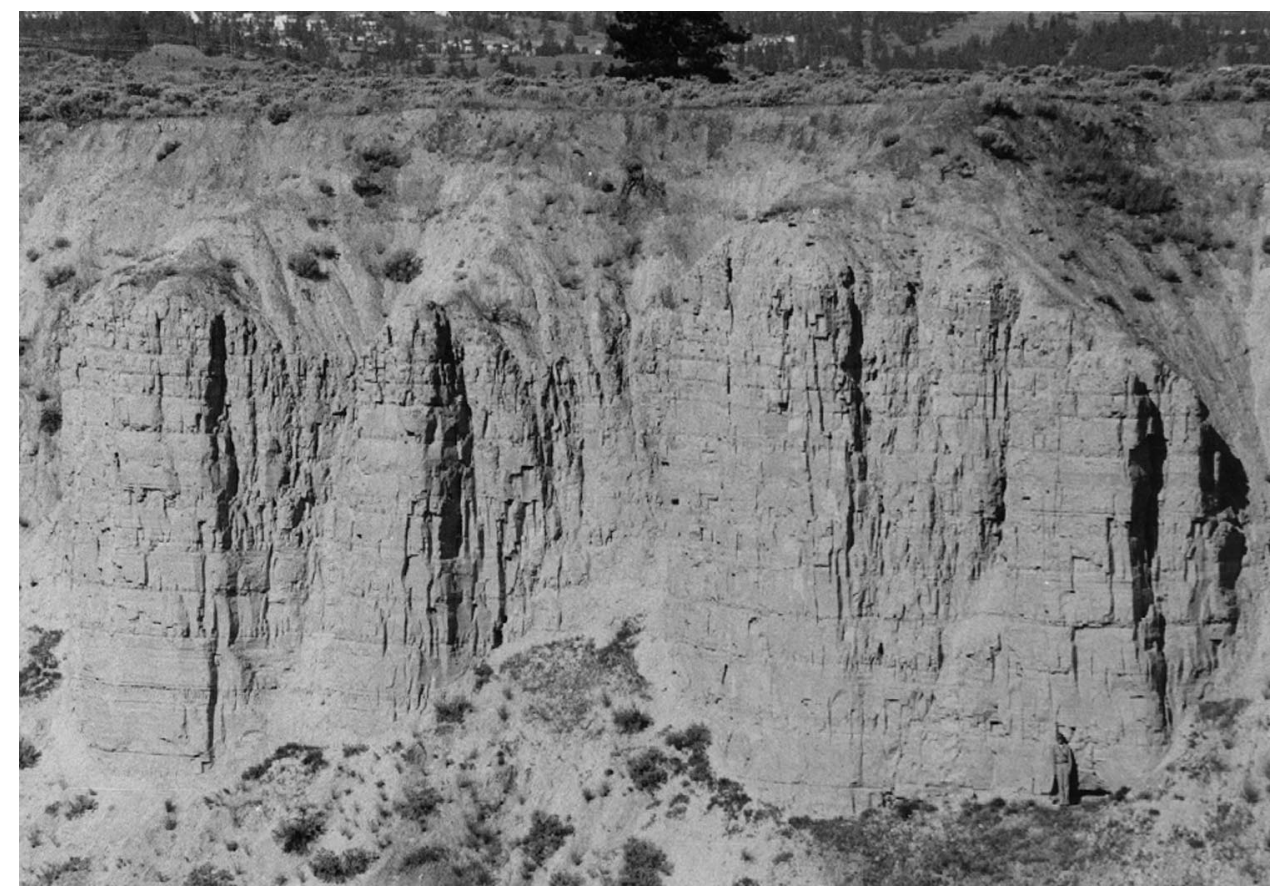

Fig. 7. Thickly varved glaciolacustrine silt in the Thompson River valley near Kamloops, British Columbia (person at lower right provides scale). The sediments were deposited over a period of a few tens of years at the end of the Fraser Glaciation.

the coast and in offshore areas (Fyles, 1963; Armstrong, 1981; Clague, 1985). Therefore, thick sediment fills accumulated in most interior and mountain valleys, on some coastal lowlands, and offshore. Remnants of fills dating to the close of the last two glaciations constitute important stratigraphic units in the Canadian Cordillera and are disproportionately large considering the brief periods of time in which they formed.

Deglacial stratigraphies, like their advance counterparts, are ordered (Fig. 8). Sequences in areas that were not drowned by the sea or by late-glacial lakes are the simplest, comprising glaciofluvial gravel and sand. These sediments commonly lie on till, but they may overlie older sediments across unconformities.

Different stratigraphies characterize valleys that were inundated by lakes during glacier retreat, a common situation in the British Columbia interior and in southern Yukon Territory. The first deglacial sediments deposited in the lakes are gravel, sand, and diamicton shed from adjacent slopes or decaying ice, or laid down by streams flowing from the ice. In some instances, this coarse debris was deposited against or over large masses of stagnant ice (Eyles et al., 1987). The ice later melted, deforming the sediments (Broster and Clague, 1987). These chaotic sediments are so coarse that they often are not recognized as being glaciolacustrine (Fig. 6). But they generally contain telltale laminated silt beds, as well as sedimentary structures that are unequivocally subaqueous in origin such as normally or inverse graded beds, foreset beds, and load casts (Shaw, 1975, 1977; a

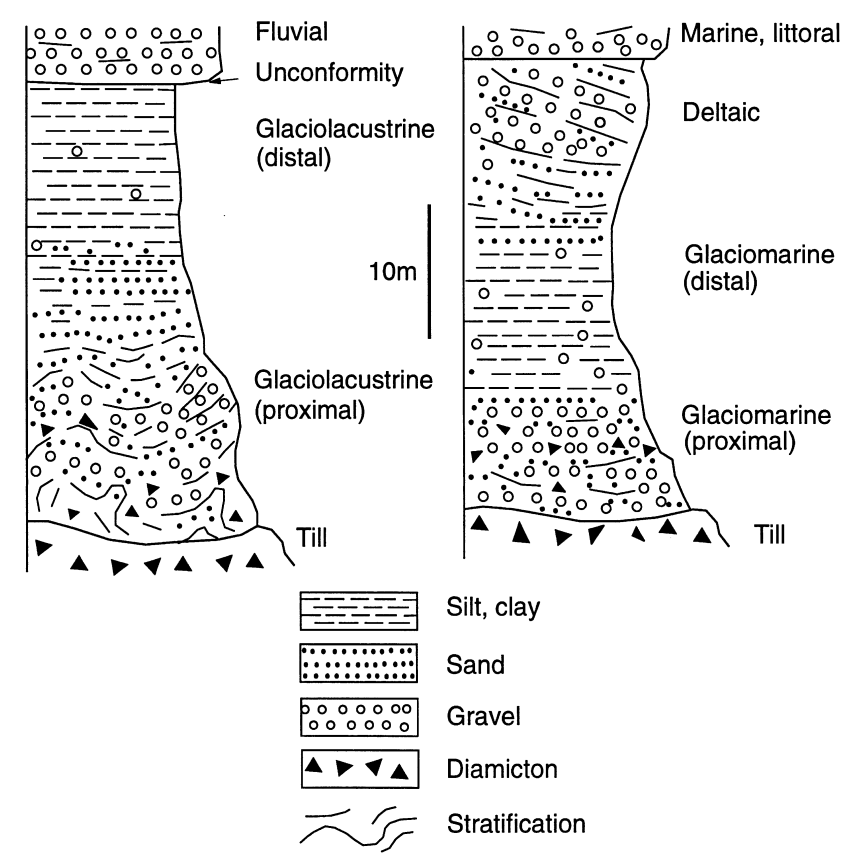

Fig. 8. Generalized stratigraphies of sediments deposited during glacial retreat in: (a) interior valleys and (b) coastal lowlands. Retreat-phase sequences comprise coarse ice-proximal facies, fine distal facies, and locally, deltaic sediments. Deltaic sediments can occur anywhere in the deglacial sequence (here, they are shown only in b). Glaciolacustrine sediments deposited in valleys at the end of the Fraser Glaciation are commonly overlain by paraglacial fluvial and fan sediments or by postglacial alluvium. 
Shaw and Archer, 1979; Eyles et al., 1987). The coarse sediments also may grade up into bedded silt and clay deposited after the ice margin had retreated from the area. Some silt and clay sequences comprise annual couplets that thin upsection (Fig. 7). The vertical change from coarse to fine facies may occur gradually over many meters, or it may be fairly sharp, albeit still conformable.

When a glacial lake drains, thick gravelly alluvium or fan deposits may bury its exposed floor (paraglacial sediments of Church and Ryder, 1972). Many present-day lakes, however, are successors of lakes that developed at the end of the Fraser Glaciation. Sedimentation in these lakes has continued without interruption for more than $10,000 \mathrm{yr}$.

Deglacial stratigraphic sequences similar to those described above are present in some coastal lowlands, although the sediments accumulated mainly in marine rather than lacustrine environments (Fyles, 1963; Armstrong, 1981; Domack, 1983; Clague, 1985). Diamicton, poorly sorted gravel, and sand deposited on the sea floor adjacent to glacier termini grade laterally and vertically into silt and clay deposited farther from the ice front. Even the distal silt and clay, however, may contain stones dropped from melting icebergs. Classic Gilberttype deltas, with gravel and sand foreset and topset beds, mark sites where meltwater streams entered the sea. Gravelly beach deposits locally cap glaciomarine sequences. The beaches formed when lowlands emerged from the sea during rebound.

More complicated stratigraphic sequences may be produced when glaciers readvance during a period of overall retreat. This happened in the Fraser Lowland near the end of the last glaciation (Armstrong, 1981; Clague et al., 1997). However, throughout much of the Cordilleran interior retreat was not interrupted by stillstands or significant readvances.

\subsection{Unconformities and nesting of stratigraphic units}

Two types of unconformities punctuate Quaternary sedimentary successions in the Canadian Cordillera: nonglacial unconformities, produced mainly by fluvial erosion and mass wasting; and glacial unconformities (Fig. 9). Nonglacial unconformities separate adjacent glacial sequences or a glacial sequence from an overlying nonglacial sequence. In contrast, most glacial unconformities occur within glacial sequences, between advance and retreat deposits. Both types of unconformities are good markers that enable one to establish position in stratigraphic sequences and to correlate units locally and regionally.

\subsubsection{Nonglacial unconformities}

Most valley fills in the Canadian Cordillera were deeply incised by streams early during the present interglaciation and also probably during earlier interglacial

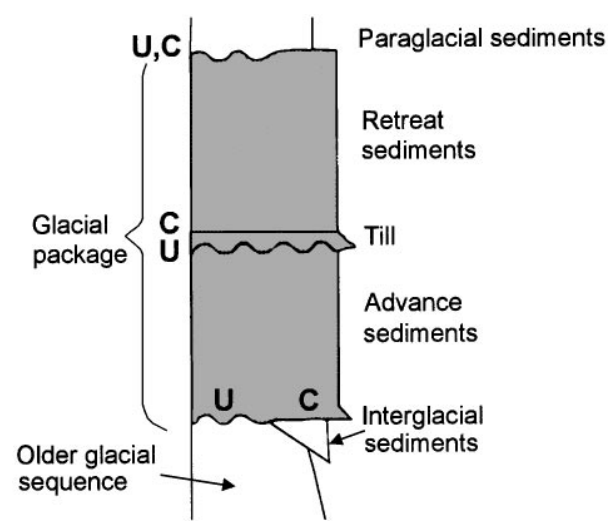

Fig. 9. Unconformities within Quaternary successions in the Canadian Cordillera. Unconformities (U) commonly occur at the bottom and top of glacial sequences (shaded) and directly below till within these sequences. Contacts between till and overlying deglacial sediments are conformable (C). Contacts between interglacial sediments and overlying advance-phase sediments and between deglacial sediments and overlying paraglacial sediments are also commonly conformable.

periods (Clague, 1989). Incision resulted mainly from a sharp reduction in sediment supply as slopes stabilized and became vegetated. In addition, base level in coastal areas was lowered up to $200 \mathrm{~m}$ due to an isostatically induced fall in the level of the sea relative to the land. The effects of this base-level lowering propagated inland and may have contributed to valley incision by streams. But, local factors such as rock ledges and constrictions may have exerted more control on down cutting than isostatic rebound. Whatever the causes, streams deeply incised deglacial and older fills before achieving quasi-equilibrium at much lower levels. Barring tectonic uplift, subsidence, or renewed glaciation, streams tend to flow at or near these low levels for long periods of time and aggradation is limited to lakes, the sea, and glacier forelands.

Base-level lowering and erosion following the penultimate glaciation produced relief similar to that of the present in many Cordilleran valleys (e.g., Eyles and Clague, 1991). The interval between the penultimate glaciation and the Fraser Glaciation was at least 40,000 yr long (Clague, 1980) and is recorded in sections in many valleys by a profound unconformity. The unconformity is overlain by thin nonglacial sediments, a soil, or more commonly thick Fraser Glaciation drift. Fraser drift fills or partially fills interglacial valleys and thus is inset into older Quaternary deposits (Ryder, 1976; Eyles and Clague, 1991). Similar, complex inset relations may exist across unconformities separating remnants of older (Middle and Early Pleistocene) valley fills.

\subsubsection{Glacial unconformities}

The Cordilleran ice sheet eroded parts of the landscape over which it flowed during several glaciations. Glaciers 
partly or completely removed sediments in fiords, in valleys oriented parallel to the direction of ice flow, and in some lowlands. In areas where all of the sediments were stripped away, young Quaternary deposits directly overlie bedrock. Where glacial erosion was less severe, remnants of older sediments are preserved below unconformities. In most valleys, glacial unconformities separate overlying deglacial units from underlying advance-phase or older Quaternary deposits. Although till may directly overlie a glacial unconformity, it is typically thin, discontinuous, or absent in valleys and cannot be reliably used as a stratigraphic marker in these settings. Thick tills occur widely outside valleys, on interior plateaus and coastal lowlands.

Glacial erosion can produce considerable local relief; consequently, units deposited immediately after deglaciation can be complexly juxtaposed against older units. Interpretations based on a simple, layer-cake stratigraphic model, in which sediment units are correlated on the basis of altitude, are likely to be incorrect.

\subsection{Preservation potential}

The extent of preservation of Quaternary sediments in the Canadian Cordillera is inversely related to their age (Fig. 10). Deposits of the Fraser Glaciation are well preserved and dominate most Quaternary successions in valleys and lowlands. In comparison, deposits of the penultimate glaciation, although present in many areas, are much more poorly preserved. Older, Middle and Early Pleistocene glacial deposits occur sporadically and provide only fleeting glimpses of the oldest glacial events in the Cordillera.

Erosion explains the decrease in preservation of Quaternary sediments with age. Glaciers repeatedly scoured Early Pleistocene sediments, and streams further dissected them during intervening interglaciations. Deposits of the penultimate glaciation were exposed for at least $40,000 \mathrm{yr}$ prior to the Fraser Glaciation and were then further eroded by late Wisconsin glaciers. Only 10,000 yr have elapsed since the end of the Fraser Glaciation, but streams and mass wasting processes have removed large amounts of Fraser drift during this time.

\section{Standard stratigraphic sequences}

\subsection{Valleys}

Quaternary deposits in valleys in the Canadian Cordillera consist mainly of one or more glacial sequences. Where two or three glacial sequences are present, they are separated by generally thin nonglacial sediments or by unconformities. The late Wisconsin sequence is the most complete and dominates nearly all valley fills. Parts of the penultimate glacial sequence can be found in most large valleys, but exposed older (Middle and Early Pleistocene) glacial deposits are rare.

A complete, late Wisconsin sequence comprises the following units from bottom to top (Figs. 5, 8a, and 10): (1) glaciofluvial gravel and sand, commonly several tens of metres thick; (2) advance glaciolacustrine sediments,
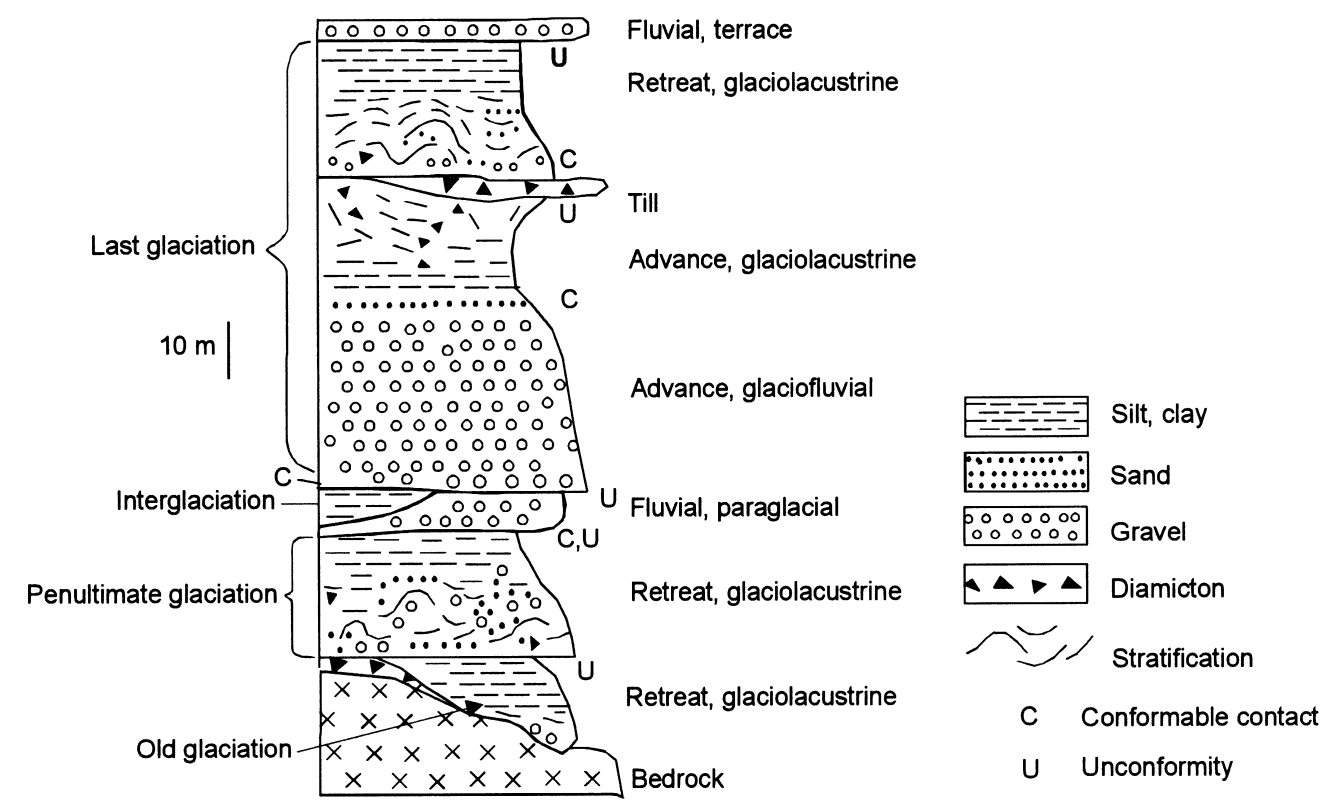

Fig. 10. Generalized stratigraphy of the Thompson River valley fill near Ashcroft, British Columbia. The succession includes deposits of three glaciations, but the two oldest glacial sequences are incomplete (i.e., advance phase sediments are missing). This stratigraphy is an example of how the Quaternary glacial record becomes increasingly fragmentary with age. 
including sand and silt deposited some distance from glacier margins and diamicton deposited adjacent to ice or to a valley wall; (3) till; (4) retreat glaciolacustrine sediments including diamicton, ice-contact and deltaic gravel and sand, and rhythmically bedded silt and clay; (5) retreat glaciofluvial gravel and sand. The late Wisconsin succession may conformably overlie middle Wisconsin nonglacial deposits, but more commonly rests unconformably on drift of the penultimate glaciation or on bedrock. Late Wisconsin deposits are overlain locally by alluvial and colluvial sediments deposited during the Pleistocene-Holocene transition, but in most places they are truncated by the present land surface. In addition to being commonly bounded by unconformities, the late Wisconsin succession contains an unconformity, located at the base of the till between advance and retreat units.

Some units of this "standard" succession are missing from most exposures of Quaternary sediments. For example, late Wisconsin, retreat-phase glaciolacustrine sediments (unit 4 above) may directly and unconformably overlie similar, but older glaciolacustrine sediments (i.e., units 1, 2, and 3 are missing). Where units are missing, one should pay particular attention to unconformities, for they provide guidance as to where preserved units lie in the stratigraphic succession.

It is worth reemphasizing that the standard succession outlined above may be too simple where more than one advance has occurred during growth of the Cordilleran ice sheet or where glaciers readvanced during deglaciation. There is little stratigraphic evidence for either of these scenarios throughout much of the Cordilleran interior, but, as mentioned before, more complex stratigraphies have been documented in peripheral glaciated areas.

\subsection{Coastal lowlands}

Quaternary stratigraphic sequences in coastal lowlands and interior valleys are similar, except that in the former areas glaciomarine sediments commonly replace glaciolacustrine sediments (Figs. 5 and $8 \mathrm{~b}$ ). Where there has been only one Fraser Glaciation advance, a complete late Wisconsin succession comprises: (1) advance glaciofluvial and deltaic gravel and sand; (2) till and ice-contact gravel; (3) retreat glaciomarine sediments, including diamicton, ice-contact and deltaic gravel and sand, and silt and clay; (4) littoral gravel and sand; and (5) retreat glaciofluvial gravel. This succession overlies either middle Wisconsin nonglacial sediments or an unconformity developed on older Quaternary deposits. The succession also contains an unconformity at the base of the till. In areas that have been isostatically uplifted above sea level, the top of the succession forms the present ground surface. Offshore, however, postglacial marine and deltaic sediments may conformably overlie retreat-phase glaciomarine deposits.

\subsection{Interior plateaus}

A relatively simple stratigraphy is found over much of the low plateaus of interior British Columbia and southern Yukon Territory. Outside river valleys, late Wisconsin till is locally overlain by retreat-phase glaciofluvial and glaciolacustrine sediments. In some areas, particularly in buried valleys, these sediments overlie older glacial and interglacial deposits; elsewhere they rest directly on bedrock.

\section{Conclusion}

Order exists in seemingly chaotic sequences of Quaternary sediments in the Canadian Cordillera. This order has been imposed by growth and decay of the Cordilleran ice sheet during the Pleistocene. Nucleation of the ice sheet in the high mountains of the Cordillera and subsequent advance of glaciers onto plateaus and into coastal lowlands led to the deposition of thick proglacial fluvial and lacustrine units in river valleys. Advancing glaciers eventually overrode these proglacial sediments, producing an erosion surface on top of which younger sediments were later deposited. The ice sheet decayed by downwasting with frontal retreat at its periphery and widespread stagnation at its center. Thick retreat-phase sediments, which constitute the upper part of each glacial sequence, accumulated in lakes impounded by decaying ice masses, in the sea on submerged coastal lowlands, and in the channels and flood plains of meltwater streams. During and just after ice retreat, streams were unable to cope with the large volumes of sediment supplied to them, and they rapidly aggraded their channels. Soon thereafter, the supply of sediment decreased, and the same streams incised valley fills. Erosion persisted through interglaciations; at these times, significant sedimentation was limited to a small portion of the landscape, mainly lakes and offshore areas.

Valley and lowland fills in the Cordillera consist mainly of discrete packages of glacial and transitional sediments separated by unconformities or by generally thin interglacial deposits. Some of the unconformities delineate former valley and lowland landscapes similar in relief to those of today. Each glacial package comprises advance and retreat sequences that reveal the pattern of ice-sheet growth and decay outlined above.

Erosion during both interglaciations and glaciations has fragmented the stratigraphic record. The most complete glacial package is that of the Fraser Glaciation. Deposits of the penultimate glaciation are common, but do not provide a complete record of that event, and only sporadic remnants of older, presumably Middle and Early Pleistocene glacial deposits are present in the Canadian Cordillera. 


\section{Acknowledgements}

Some of the ideas presented in this paper were formulated in discussions with J.E. Armstrong, M.A. Church, R.J. Fulton, J.M. Ryder, and W.H. Mathews. A benchmark paper on paraglacial sedimentation by Church and Ryder (1972) was particularly influential in developing my thoughts on episodic sedimentation controlled by glaciation. Tonia Williams drafted the figures, and R.J. Fulton, R.B. Waitt, and an anonymous referee reviewed drafts of the manuscript.

\section{References}

Armstrong, J.E., 1981. Post-Vashon Wisconsin Glaciation, Fraser Lowland, British Columbia. Geological Survey of Canada Bulletin 322, $34 \mathrm{pp}$.

Broster, B.E., Clague, J.J., 1987. Advance and retreat glacigenic deformation at Williams Lake, British Columbia. Canadian Journal of Earth Sciences 24, 1421-1430.

Church, M., Ryder, J.M., 1972. Paraglacial sedimentation: a consideration of fluvial processes conditioned by glaciation. Geological Society of America Bulletin 83, 3059-3072.

Clague, J.J., 1975. Late Quaternary sediments and geomorphic history of the southern Rocky Mountain Trench, British Columbia. Canadian Journal of Earth Sciences 12, 595-605.

Clague, J.J., 1976. Quadra Sand and its relation to the late Wisconsin glaciation of southwestern British Columbia. Canadian Journal of Earth Sciences 13, 803-815.

Clague, J.J., 1980. Late Quaternary Geology and Geochronology of British Columbia. Part 1: Radiocarbon Dates. Geological Survey of Canada Paper 80-13, 28pp.

Clague, J.J., 1981. Late Quaternary Geology and Geochronology of British Columbia. Part 2: Summary and Discussion of Radiocarbon-dated Quaternary History. Geological Survey of Canada Paper 80-35, 41pp.

Clague, J.J., 1983. Glacio-isostatic effects of the Cordilleran ice sheet, British Columbia, Canada. In: Smith, D.E., Dawson, A.G. (Eds.), Shorelines and Isostasy. Academic Press, London, pp. 321-343.

Clague, J.J., 1985. Deglaciation of the Prince Rupert - Kitimat area, British Columbia. Canadian Journal of Earth Sciences 22, 256-265.

Clague, J.J., 1986. The Quaternary stratigraphic record of British Columbia - evidence for episodic sedimentation and erosion controlled by glaciation. Canadian Journal of Earth Sciences 23, 885-894.

Clague, J.J., 1987. Quaternary stratigraphy and history, Williams Lake, British Columbia. Canadian Journal of Earth Sciences 23, 885-894.

Clague, J.J., 1988. Quaternary stratigraphy and history, Quesnel, British Columbia. Géographie physique et Quaternaire 42, 279-288.

Clague, J.J., 1989. Quaternary geology of the Canadian Cordillera. In: Fulton, R.J. (Ed.), Quaternary of Canada and Greenland. Chapter 1. Geological Survey of Canada, Geology of Canada No. 1, pp. 15-96.

Clague, J.J., Armstrong, J.E., Mathews, W.H., 1990. Advance of the late Wisconsin Cordilleran ice sheet in southern British Columbia since 22,000 yr BP. Quaternary Research 13, 322-326.

Clague, J.J., Mathewes, R.W., Guilbault, J.-P., Hutchinson, I., Ricketts, B.D., 1997. Pre-Younger Dryas resurgence of the southwestern margin of the Cordilleran ice sheet, British Columbia, Canada. Boreas 26, 261-278.

Davis, N.F.G., Mathews, W.H., 1944. Four phases of glaciation with illustrations from southwestern British Columbia. Journal of Geology 52, 403-413.
Domack, E.W., 1983. Facies of late Pleistocene glacial-marine sediments on Whidbey Island, Washington. In: Molnia, B.F. (Ed.), Glacial-Marine Sedimentation. Plenum Press, New York, pp. 535-570.

Eyles, N., Clague, J.J., 1987. Landsliding caused by Pleistocene glacial lake ponding - an example from central British Columbia. Canadian Geotechnical Journal 24, 656-663.

Eyles, N., Clague, J.J., 1991. Glaciolacustrine sedimentation during advance and retreat of the Cordilleran ice sheet in central British Columbia. Géographie physique et Quaternaire 45, 317-331.

Eyles, N., Clark, B.M., Clague, J.J., 1987. Coarse-grained sediment gravity flow facies in a large supraglacial lake. Sedimentology 34 , 193-216.

Flint, R.F., 1971. Glacial and Quaternary Geology. Wiley, New York.

Fulton, R.J., 1967. Deglaciation Studies in Kamloops Region, an Area of Moderate Relief, British Columbia. Geological Survey of Canada Bulletin 154, 36pp.

Fulton, R.J., 1975. Quaternary Geology and Geomorphology, NicolaVernon Area, British Columbia. Geological Survey of Canada Memoir 380, 50pp.

Fulton, R.J., 1991. A conceptual model for growth and decay of the Cordilleran ice sheet. Géographie physique et Quaternaire 45, 281-286.

Fulton, R.J., Smith, G.W., 1978. Late Pleistocene stratigraphy of southcentral British Columbia. Canadian Journal of Earth Sciences 15, 971-980.

Fyles, J.G., 1963. Surficial Geology of Horne Lake and Parksville Map-areas, Vancouver Island, British Columbia. Geological Survey of Canada Memoir 318, 142pp.

Hicock, S.R., Hebda, R.J., Armstrong, J.E., 1982. Lag of the Fraser glacial maximum in the Pacific Northwest: pollen and macrofossil evidence from western Fraser Lowland, British Columbia. Canadian Journal of Earth Sciences 19, 2288-2296.

Huntley, D.H., Broster, B.E., 1994. Glacial Lake Camelsfoot: a Late Wisconsinan advance stage proglacial lake in the Fraser River valley, Gang Ranch area, British Columbia. Canadian Journal of Earth Sciences 31, 798-807.

Kerr, F.A., 1934. Glaciation in northern British Columbia. Royal Society of Canada Transactions, Series 3, 28, 17-31.

Ryder, J.M., 1976. Terrain Inventory and Quaternary Geology, Ashcroft, British Columbia. Geological Survey of Canada Paper 74-49.

Shackleton, N.J., Opdyke, N.D., 1973. Oxygen-isotope and palaeomagnetic stratigraphy of equatorial Pacific core V28-238: oxygen isotope temperatures and ice volumes on a $10^{5}$ year and $10^{6}$ year scale. Quaternary Research 3, 39-55.

Shackleton, N.J., Opdyke, N.D., 1976. Oxygen-isotope and paleomagnetic stratigraphy of Pacific core V28-239, late Pliocene to latest Pleistocene. In: Cline, R.M., Hayes, J.D. (Eds.), Investigations of Late Quaternary Paleoceanography and Paleoclimatology. Geological Society of America Memoir 145, pp. 449-464.

Shaw, J., 1975. Sedimentary successions in Pleistocene ice-marginal lakes. In: Jopling, A.V., McDonald, B.C. (Eds.), Glaciofluvial and Glaciolacustrine Sedimentation. Society of Economic Paleontologists and Mineralogists Special Publication 23, pp. 281-303.

Shaw, J., 1977. Sedimentation in an alpine lake during deglaciation, Okanagan Valley, British Columbia, Canada. Geografiska Annaler 59A, 221-240.

Shaw, J., Archer, J., 1979. Deglaciation and glaciolacustrine sedimentation conditions, Okanagan Valley, British Columbia, Canada. In: Schluchter, C. (Ed.), Moraines and Varves, Origin/Genesis/Classification. A.A. Balkema, Rotterdam, pp. 347-355. 